\title{
The Day after Music Education
}

\author{
Guillermo Rosabal-Coto, Guest Editor \\ Facultad de Artes, Universidad de Costa Rica \\ Latin American Studies Program, University of Toronto
}

This special issue is framed conceptually and contextually, and expands on the theorization undertaken by authors from a North-South border perspective. In the first section, I explain foundational decolonial terms, while I suggest political meanings and implications of the rising interest in decolonization in music education scholarship. In the following section, I discuss practical challenges brought by Western-based ontology and epistemology in music socialization, from my particular border position as colonized/colonizer. I close the article with a call for decolonization for music education practitioners, and researchers in both the global North and South.

Keywords: coloniality, decolonization, inner colonialism, music education, music socialization

\section{Opening: A(n) (un)wanted metaphor?}

In the last few years, invitations to write articles/book chapters, or attend academic gatherings on decolonization issues in performative arts, musicology and ethnomusicology, social sciences, humanities, and education have bloomed in both the Global North and South, in places like Barcelona (Spain), Ontario (Canada), and Kuala Lumpur (Malaysia). Decolonization, as concept, has been the most important legacy of the Bandung Conference (1959), as an option to Western, White, Eurocentric supremacy (Mignolo 2011). As a process, it entails unveiling, questioning, dismantling, and removing structures that sustain material and symbolic colonization. Perhaps the most important thing we should bear in mind in any attempt to operationalize decolonization is the powerful declaration in Tuck and Yang's 2012 landmark article title: "Decolonization is not a metaphor" (1), an idea that we, the authors in this special issue, take seriously.

(C) Guillermo Rosabal-Coto. 2019. The content of this article is the sole responsibility of the author. The ACT Journal and the Mayday Group are not liable for any legal actions that may arise involving the article's content, including, but not limited to, copyright infringement. 
The first journal to publish a special issue on decolonization of music education was ISME's Revista Internacional de Educación Musical, which goes by the acronym RIEM, in late 2017. I co-edited this issue, titled Hacia una educación musical decolonial en y desde Latinoamérica (Towards a decolonial music education in and from Latin America) (Shifres and Rosabal-Coto 2017). The issue aimed at raising awareness of the term coloniality, broadly understood as

the logics through which colonial power structures have coordinated and imposed a racist concept of human being, as well as other modes of knowing and being in the universe, devaluing other bodies, languages, cultures, religions, economies, ways of social organization and subjectivities. (Shifres and RosabalCoto 2017,86 )

Coloniality serves to operationalize the alleged racial and ethnic superiority of (European) civilization and modernity, and more recently the so-called First World countries, with the aim of justifying colonization and colonialism. Coloniality sustains the sovereign gaze of those entitled by God, reason, or Eurocentric history to observe others-to-be observed, without being seen. This is the hubris view, or hubris of zero degrees (Castro-Gómez 2008)-meaning the "zero" point from which every direction is drawn on a Western map.

Broadly speaking, colonization takes place when an elite social class or hegemonic community imposes a world view and the supporting material structures to individuals and communities, with the aim of material or symbolic exploitation (Wynter 2003). It is set in motion through force, ideology, discourse, and culture. Historical colonialism constitutes the domination, exploitation, genocide, and enculturation initiated in the sixteenth century with the arrival of Europeans to the territories of Turtle Island (now Canada and the United States), Valle de Anhánuac (now Valley of Mexico), Abya-Yala (now Panama and Colombia), and Tawantinsuyu (Andean region in South America). Inner colonialism denotes postindependence processes in which local elites from former colonies appropriate material and symbolic structures inherited from past colonial relations, to maintain and impose "the biopolitical and geopolitical management of people, land" and natural resources "within the 'domestic' borders of the imperial nation" (Tuck and Yang 2012, 4). It uses modes of control such as schooling and policing "to ensure the ascendancy of a nation and its white elite" (5). In North America, it is known as settler colonialism (Tuck and Yang 2012). 
Due to the unprecedented and unequalled dimension of extraction of raw materials, human exploitation, and genocide through historical colonialism, coloniality has been considered the dark side of modernity (Mignolo 2007). Coloniality permeates every dimension of human existence-from materiality to sexualityand decolonial thinking usually theorizes it as: a) coloniality of power (control of authority), b) coloniality of being (control of subjectivity), and c) coloniality of knowledge (epistemological control) (Quiijano 2000; also see Mignolo 2007 and Wynter 2003).

According to Quijano and Wallerstein (1992), it is necessary to understand coloniality and the invention of race to understand the modern world order (capitalist world economy) (see Cox 1959) - not to be equated with "globalization"beyond units of analysis like "society" and "national state." Globalization is the culmination of a process that began with the constitution of the American continent and Eurocentric colonial/modern capitalism, and not the process of colonization itself. Neocolonialism is a form of colonialization that "can be traced back to the 1990s, when the inability of many postcolonial nations to deal with debt and economic domination became overwhelming, and continues to this day" (RosabalCoto 2016b, 18), through the organization of asymmetrical financial and political relationships between less developed and industrialized countries, around the latter's agendas (Santos 2010). Neocolonialism reconfigures the discourse of civilization, disguising it as development (Silva 2011).

Understanding coloniality allows us to demonstrate that European modernity was the outcome of the material and symbolic subjugation of the territories and peoples of what became the American continents, so that modernity was not "an additive or collateral effect of modernity, through the European expansion and its resulting global market" (Rosabal-Coto 2016b, 39-40; Castro-Gómez 2008), as Marx proposed. In fact, the Marxist categories of "false consciousness," "mode of production," and "class struggle" fail to make visible the financial and political roots of colonialism (Castro-Gómez 2008, 264).

RIEM's publication outreach among the English-speaking audience may have been modest. I would like to acknowledge it as a landmark that precedes the issue hereby presented. It scrutinizes ways in which hegemonic Eurocentric and neoliberal ontologies and epistemologies coordinate a range of institutionalized settings and practices: a) conservatory music theory teaching and learning (Castro 2017; Holguín 2017), b) Western music notation (Burcet 2017), c) devaluation or

Rosabal-Coto, Guillermo. 2019. The day after music education. Action, Criticism, and Theory for Music Education 18 (3): 1-24. https://doi.org/10.22176/act18.3.1 
misappropriation of Indigenous music practices (Vázquez Córdoba 2017), and c) nature extractivism as material foundation to instrument manufacture for massive orchestral programs (Lafontant Di Niscia 2017). Some authors envision the pertinence of pedagogical approaches counter to Eurocentric and neocolonial models, grounded on premises of pluriversality and interculturality (Carabetta 2017; Gonnet 2017), as well as on revolutionary Latin Americanist thinking (Serrati 2017). Previous work by a few scholars involved in this publication set an important precedent to discussing relationships between coloniality and music education (Holguín and Shifres 2015; Rosabal-Coto 2016a, 2016b, 2013; Shifres and Gonnet 2015).

The MayDay Group's ACT call for papers for the special issue on decolonization of music education came out during the year following RIEM. It was envisioned as the first ACT multilingual issue, with special interest in decolonial theory and practice from the Global South and was commissioned by the former Editor of ACT to a MayDay Group ACT Editorial Board member, native Spanish speaker living in the world's most unequal region-Latin America. An initiative for the creation of a Decolonizing and Indigenizing Special Interest Group (SIG), led by music educator and MayDay Group member Anita Prest (University of Victoria, Canada) deserves mention, too. It was raised to the General Board of ISME in early 2019. According to ISME rules, establishing the SIG required "20 paid-up members from 3 areas of the globe to support this initiative" (personal communication with Anita Prest, October 3, 2019). It was signed mostly by North American and European English-speaking scholars in musicology and music education. ISME 2020 World Conference, to take place in Finland-a country perceived by many as a model of education to which to look-has announced its theme: "Visions of equity and diversity," a venue where discussions on decolonization might find room.

Despite how optimistic this picture may look, it caught my eye that most initiatives to discuss or write about decolonization were coming from or were hosted by so-called "historically White institutions" arrayed in industrialized countries and the Western art/culture tradition. Through a glance from the Global South, both ISME and MayDay Group might somehow be associated with institutional Whiteness by way of their Western-based epistemological foundations and array in the Western art music tradition and pedagogy, not to mention their predominantly White Euro-American membership. It is widely known, however, that ISME has taken interest in challenging top-down pedagogical Western approaches,

Rosabal-Coto, Guillermo. 2019. The day after music education. Action, Criticism, and Theory for Music Education 18 (3): 1-24. https://doi.org/10.22176/act18.3.1 
especially with the establishment of a special interest group (SIG) on community music. The MayDay Group has led initiatives for the scholarly discussion of global theories and practical issues on oppression, inequality and exclusion, and social justice (e.g., Hess 2017), such as antiracism, ableism, sexism and institutional injustice (e.g., Bradley 2017). The above may signal both awareness, on the one hand, and curiosity, on the other, that music education has been both a source and vehicle of colonization, and that this deserves serious conversation and inquiry. Such actions may pave the way to the exercise of an anticolonial awareness, understood as the acknowledgement of "[ $t]$ he political struggle of colonized peoples against the specific ideology and practice of colonialism" (Ashcroft, Griffiths, and Tiffin 1998, 14), although it is necessary "to reject colonial power and restore local control" (14) in order to accomplish decolonization.

And yet, an impressive contingent of music scholarship is constantly produced that seeks to back up old and new relationships that explain "the good" in music learning and the benefits of music socialization, that justify the universality of music in abstract terms, almost non-cognizant of the geocultural, peripheral contexts-individuals and communities-where such "truths" may be adopted. Is the interest in decolonization another attempt to find the good and humanity in concepts and practices that for centuries have classified, excluded, intervened, modified, and oppressed people in the name of High Art or Western citizenship? Could this interest be a quest to fantasize or romanticize the potential of a profession in times of crisis? Perhaps these organizations and institutions envision decolonization as resistance to and deconstruction of enduring paradigms and practices, but in the spirit of Tuck and Yang's 2012 premise, are they willing to unveil, dismantle, and transform structures of exploitation of territories, lands, possessions, living beings, bodies, minds, world views, customs, ways of thinking, feeling, knowing, and learning in music education settings?

This brings to mind an ominous acknowledgement by a past ACT Editor: "The music education profession has a long, not always inspiring history of embracing fashions and trends, only to drop them when the next comes along" (Bowman $2007,1)$. Troubled by this possibility, I cannot help appropriating two simple questions by the same author, from the title of his editorial article to a special issue on social justice and music education: "Who's asking? (Who's answering?)" (1), and paraphrasing other title questions from a similar work: Why decolonial? "Why now"? (2006, 5; my emphasis).

Rosabal-Coto, Guillermo. 2019. The day after music education. Action, Criticism, and Theory for Music Education 18 (3): 1-24. https://doi.org/10.22176/act18.3.1 
I find it very hopeful that in this special ACT issue, young scholars have engaged in a good deal of theorization on coloniality in institutionalized music education contexts and practices globally, because they respond to the whos and whys of decolonization in Western music education, expanding the Latin American scope of the RIEM special issue to the United States, South Africa, and the United Kingdom. At the time of submission, the authors were advanced graduate students, and some were in their dissertation research processes. It is also significant that most of them were immigrant students or teachers living outside their native countries, because whether or not they decided to make it explicit in their writing, we bring particular webs of interactions and personal experiences of dislocation and enculturation into our concerns and theorization-as in the next section of this article. This is an acknowledgement that we must make if we want to move beyond decolonization as metaphor. Furthermore, these authors come from related fields that can engage in conversation: ethnomusicology, education, and sociology. We took care during the review process to make explicit connections between a) coloniality and specific concepts, notions, and practices, b) coloniality and the specific national/cultural macro context for the issues addressed. We did not impose specific frameworks or writing styles, especially when it came to syntax and grammar in non-English languages, when we reviewed the translations.

Rupert Avis explores how Orientalist and neoliberal discourses emerge in bimusical education in a higher music education institution in India. He also envisions how bi-musical education could be a setting for decolonial practices, through the lens of Santos' (2010) concept ecology of knowledges. Luis Chávez and Russell Skelchy discuss colonizing world views and concepts in ethnomusicology as music education, specifically in the context of the US-based Society for Ethnomusicology (SEM); they explore past and current actions within SEM as potential steps to decolonization processes. Gavin R. Walker analyzes the challenges of decolonial thinking for informing research in a historically White university in the context of post-apartheid South Africa, drawing from a first-person experience of vulnerability in a music research institute. Brazilian, Euridiana Silva Souza, identifies and discusses colonial Eurocentric values that permeate higher music education curricula in Brazil. Héctor Miguel Vazquez Córdoba (Mexico) and Attilio Lafontant Di Niscia (Venezuela) expand on the concerns raised in their RIEM articles. Vazquez Córdoba proposes an educational philosophy based on Land-centeredness to frame the inclusion and practice of Indigenous musics in education contexts.

Rosabal-Coto, Guillermo. 2019. The day after music education. Action, Criticism, and Theory for Music Education 18 (3): 1-24. https://doi.org/10.22176/act18.3.1 
Venezuelan sociologist Lafontant Di Niscia demonstrates, through a case study, how tonewood exploitation and the import of musical instruments for Venezuela's El Sistema contributes to environmental injustice, beneath the latter institution's social welfare discourse. He proposes an ecological epistemology of music education, inspired on the South American suma kawsay world view.

Considering that the authors have theorized in relation to pedagogical, curricular, and research practices in institutional webs of interaction, I consider it crucial to expand a few practical instances of coloniality, inner colonialism, and neocolonialism in relation to other webs of interaction not explicitly mentioned here (or not at all), to address to both North and South audiences. To this aim, I make the following methodological choices:

a) Identify and exercise my locus of enunciation as a South-North border location. In her work Borderlands/La frontera: The new mestiza (1987), Gloria Anzaldúa took a "radical epistemic position that delinks and moves forward from the geopolitics of knowledge centered on universal, racial, and cultural homogeneity constructed by colonialism, through the prototype of the White, heterosexual, European man" (Rosabal-Coto 2016b). Anzaldúa enunciates the critical conscience "of being a female Mestiza in an Indigenous struggle, standing in the middle of a borderland," a consciousness "that comes with the site of enunciation of the Mestiza operates in favor of decolonization of knowledge and of being" (41). I frame my discourse within Anzaldúa's ontological and epistemological positioning, and in doing so, I exercise border epistemology. I deliberately emphasize concrete and detailed personal examples, as opposed to generalization and abstraction on experiences of colonization.

b) Avoid, as much as possible, the routine use of Western concepts like culture, art, music, music education, inequality, social justice, ethics, artistic citizenship, postmodernism, globalization, discourse, and categories of analysis such as identity, race, gender, and social class. In my postcolonial institutional ethnography analysis of music learning socialization from the standpoint of music learners/teachers in my own geocultural context (Rosabal-Coto 2016b), I emphasized how the extensive use of such concepts and categories had the potential to erase the materiality of people's lives, resulting in abstract, overly theoretical depiction of human activity coordination by socio-material macro structures of colonial origin, in educational research. I also suggested that this might very well apply to 
educational contexts in industrialized countries, a thought that becomes fundamental in the third section of this article.

I suggest connections of the instances discussed, with material and symbolic macro processes and structures, in the epistemological line of institutional ethnography (Smith 2005). This method seeks discovery of the coordination of everyday life by institutional practices, through the mapping of micro texts (e.g., notions, practices) that are coordinated from macro structures, (usually) for the goals of capitalism, in antagonism with the bodily locations of people (Rosabal-Coto 2016b; Smith 2005). This expands and complements the extensive theorization already undertaken by the authors in this special issue (and hopefully in other edited or inpreparation publications on decolonization that pair up with this one), in relation to coloniality. I do not seek to summarize or reiterate what these authors have already written, but to strengthen their work in an overtly decolonial strategy, consciously exercising the power bestowed as Guest Editor, from a border location.

c) Close the article with a letter from a respectful colleague, beyond "hard," abstract, academic writing. The latter is not "a paper without the theory," but the exercise of weaving my loom with conceptual threads not dictated by concepts, but by questions, with the intent to challenge current practices in music education and envision venues for decolonization, while hopefully accomplishing emotional proximity with the reader.

\section{"Development": We - you - they colonize, from a border location}

I am aware of the person whom I have co-constructed myself to be when asking and answering questions about colonialism, colonization, and coloniality. I acknowledge I am and have been both colonized and (inner) colonizer. Chances are that I will remain as such, sometimes willingly, sometimes not, as my multiple empirical selves negotiate desire and survival in everyday life roles and choices that intersect my musical socialization. For instance, since I am fair-skinned, people at home often mistake me for a blonde-which goes by the Costa Rican Spanish colloquialism macho. This trait is likely to be associated with wealth and possessing some kind of formal education or elite upbringing or denotes being born in a nonLatin American industrialized country. As a fair-skinned, native Costa Rican, I could be considered White, an heir to Euro-American culture, easily fitting into the (derogatory) label gringo-in other words, a foreign colonizer. 
I cannot deny that this gives me a position of power and respect, especially in trade and business, or in positions of authority, including parenthood and teaching. Apparently, I can colonize at will. Ironically, though, as a gringo, one is exposed to being outsmarted or abused by those who long for your wealth or feel intimidated by your education and manners as, for instance, in some customer service transactions. In my country, we call the capacity to trick an authority or the establishment malicia indígena (Sp. Indigenous malice). An example of this, in Western social science research, could be how gregarious researchers who participated in Margaret Mead's landmark study of sexual behavior in Samoa acknowledged how they had distorted information, giving the White researcher the information for which she seemed to be looking (Freeman 2000).

Paradoxically, my fair skin does not get me into a position of power in interactions in academic circles in Europe and North America. The declaration of my Central American nationality on my passport and immigration paperwork, and my communication through accent, voice tone, and bodily gestures at conferences never fail to give me away, even if I try to conceal this fact by hinting that my language, thinking, taste, or attitude are just the same as my international host's. Instead, I am considered a second-class citizen, not White, but Hispanic or Latino. Such "hints," by the way, can be highly intimidating to my students at home.

Just like a gringo can be challenged by malicia in my country, I have experienced the dilemma of making my move to gain acceptance internationally, so as to not be discriminated against, and also in order to be able to qualify for privileges like being invited to teach, write, get travel funding or expensive research materials that are unavailable at home. In other words, I exercise my malicia indígena. An unfortunate side of this action, however, is that malice may require self-oppression, like forcing my body to sit for hours to read and write, as opposed to other less rational and static tasks through which I could, too, contribute to advancing knowledge.

I was born and have resided in a region and country constructed as Third World or undeveloped by the official Western history and scientific legacy, and treated as such by policy emanating from the White House and financial measures by international funding agencies like the World Bank and Inter-American Development Bank (Silva 2011). Hegel believed that "Latin American nations were outside of history because they had not developed the institutions and philosophical thought that would have allowed them to belong into the progressive movement

Rosabal-Coto, Guillermo. 2019. The day after music education. Action, Criticism, and Theory for Music Education 18 (3): 1-24. https://doi.org/10.22176/act18.3.1 
toward liberty characteristic of Universal History" (Rosabal-Coto 2016b, 39; also see Castro Gómez 2008). As Colombian sociologist Castro-Gómez (2008) warns, Marx believed that Latin America was "a grouping of semi-feudal societies governed by large landowners that wielded their despotic power without any organized structure." Marx did not consider Latin America capable "of developing socioeconomic structure that would allow it to be incorporated into a global revolutionary process with any measure of success" (262).

It is usual that travelers (and even colleagues) I run into on my way to/from international conferences in Europe and North America still mistake Costa Rica geographically for the island (US commonwealth) of Puerto Rico. Lonely Planet guide recommends it as an exuberant and hospitable place for Europeans and North Americans to spend winter holidays and for retirement. Often colleagues from the North look at undeveloped Costa Rica with awe because wild flowers seem to grow there (Johnson 2010). More recently, Costa Rica has been advertised on the web as sex paradise for Northern tourism.

When I present my work in North America and Europe, colleagues seem to take for granted that I work in the same kind of educational settings, cater to the same kind of students, and have the same personal and professional goals. Just like Niknafs (2018), as a Middle East woman settling in North America, I have to explain that what has consensually been defined as music education in the North is not what this practice means in Latin America. More importantly, the material and environmental conditions where music socialization takes place are not the same. For example, only private schools can afford to have music classrooms equipped similarly to public schools in North America. The dimensions of places like homes and public areas like sidewalks are usually narrower than in North America, and in Central America we do not have four seasons, we have two. How can we attempt to universalize something as contextual and relative, as space and temporality, and other life experiences we cannot see, like selfnotion, notion of others, of sound, and (of course) music?

I am reminded by international media of being Third World, or undeveloped, when caravans of Central American immigrants set out for the North by foot and in trucks, hoping to cross the Mexican-US border in their quest to escape poverty and other forms of structural violence, and the US President mandates the separation of children from their families-upon which they experience the traumas of separation and for some, sexual abuse. I am reminded of these labels, too, when a

Rosabal-Coto, Guillermo. 2019. The day after music education. Action, Criticism, and Theory for Music Education 18 (3): 1-24. https://doi.org/10.22176/act18.3.1 
billion dollars are raised overnight to restore Notre Dame, and when the Facebook hive bursts into a massive clamor of "I am Paris," while nobody bets on being Haiti after the 2010 earthquake, Puerto Rico after hurricane María in 2017, Nicaragua after continuous arrest and killing of antigovernment college students (2018-ongoing), or Venezuela in its current humanitarian emergency. The message is that some bodies and communities that are simply expendable by virtue of not belonging to the territories and individuals within the Western path of progress and development.

I can assure you that I was raised to be a colonizer. I had the opportunity to attend elite private preschool, primary, and secondary schools in Costa Rica. In Latin America three decades ago, this broadly meant that one received most of their formal education in a second (imperial) language-usually English, and learning a third (also imperial) language was probably included. My father was a medical doctor who earned a graduate degree abroad, and my mother was the daughter of a European-trained doctor who served during the Italian Intervention in the First World War, served as Ambassador in Italy, and was a social democrat deputy in the Costa Rican congress. Both my parents underwent private schooling at Catholic institutions run by European religious congregations in Costa Rica and were raised to fulfill traditional parental roles and citizenship. They envisioned private education for their offspring as a vehicle for upward mobility-in other words, for travelling the path of progress.

Moreover, everyday socialization with cultural products on foreign mass media at home-mostly TV series, US-designed toys manufactured in China, and books-only strengthened my enculturation into Euro-American lifestyle and values. This is how I interiorized the premise that the "real" lives and deeds took place in cities like New York, Chicago, Los Angeles and (of course) Paris and Madrid, and that my equals and I should naturally aspire to live the dreams and lifestyles of the characters portrayed on those media. I was able to assimilate three Euro-American languages-Spanish, English, and French-through painstaking rote instruction, and more importantly, the world views and cultural values and stereotypes that came with them. By the same token, my English education based on learning the grammar structures, vocabulary, the standard English literature (e.g., I read and analyzed Shakespeare's and Middle English literary works under the guidance of native speakers), had a lot to do with my capacity to craft stories, something which I have capitalized for narrative research and ethnography, as I do in this article.

Rosabal-Coto, Guillermo. 2019. The day after music education. Action, Criticism, and Theory for Music Education 18 (3): 1-24. https://doi.org/10.22176/act18.3.1 
Through social studies in elementary school, I learned that we had been "discovered" by Christopher Columbus on his fourth trip to the West Indies, when he landed on the Atlantic coast of Costa Rica in 1502. The Costa Rican monetary unit was named after him-Colón. In elementary school we sang Himno a Colón (Hymn to Columbus) to the music of a military march, which glorified the sovereignty (sic) of this sailor. I also recall a school song that lauded the Catholic Queen of Spain, who, according to the legend, sold her jewels in order to provide the Genovese admiral with the funding for his enterprise. At school we prepared performances to celebrate El Día de la Raza (The Day of Race) on October 12. At those performances, "Indian" and "Aboriginal" student actors were characterized as the US Apache Indians who appeared on Westerns. It was common, too, that the teachers chose children to depict the characters according to their skin color and traits. This was a subtle, (but legitimate) way to associate skin colors and traits with the ways of life and knowing that may or may not have been valid.

Along with socialization on values and lifestyles from the North, my family upbringing was rooted in strict Catholic values, handed down through Spanish colonization and the arrival of many religious congregations from Central Europe. Such upbringing repressed my not-being-interested-in-girls; that part of me just did not fit the "right way" being taught by institutions like the Church and school, as passed down through the Eurocentric idea of human being/citizen emulated by a national identity invented by an oligarchic elite after Costa Rica was granted its independence by the Spanish Empire in the 19th century (see Rosabal-Coto 2006, 2016a). As Costa Rican cultural critic and sexuality scholar Schifter (1989) has expounded, homosexuality in Costa Rica was not ranked as a pathology, but as a felony.

I managed, though, to make my place in the Catholic Church as an adult altar server, liturgical singer, and choral conductor, and in the latter role I auditioned for admission to a Canadian graduate degree program in music education. I channeled my sexuality through such vocation for service. It is within the Catholic religion that I interiorized charity as a way to save the other in (my perceived) need. I reaffirmed that due to my advantaged education, knowledge, and religious affiliation, I was entitled to tell students and other "inferiors" (e.g., dispossessed, illiterate, disabled, sinful, and non-Catholics) the path they should travel when making personal choices at school and in life. Several decades later, I still feel ashamed for 
such arrogance and realize how much I could have learned from those "inferiors" had I had an attitude of listening, without wearing the colonizer hat.

It is when I travel to present at conferences or conduct workshops or work with graduate students outside Latin America, however, that I feel more confident and in a safer environment to come out as gay, and even speak of such dislocation as an example of inner colonialism. Am I trying to liberate myself by entering a "developed" circle inaccessible to many of my people in Latin America?

Lastly, my family had the financial capacity to afford a good quality, brand new bassoon-one of the most expensive musical instruments manufactured outside Latin America-when I was in college. Behind my need to get an instrument of my own lay the wholehearted desire to become in the sound and bearing of those celebrated European performers to whom I listened on records and CDs. My desire was so intense that I was willing to undergo extensive mistreatment of my own physical body: it was normal to have sore lips in my quest to handle very hard reeds in order to be able to produce the dark, German school tone on my instrument.

Next to this longing, as a college freshman I used to spend entire school nights at an older, conservatory teacher-friend's house watching opera videos from $L a$ Scala, Arena di Verona, and the New York Met, learning about a genre that fascinated my imagination. This was a mechanism to find positive personal connections to overcome parental authoritarianism and family unacceptance, but was a I colonizer because I sought peace of mind for being coerced into denying who I was, in listening to European opera?

All the above socialization backed me up to the extent of being able to be employed as a music teacher, to gain a master's degree in choral education in North America, as well as a Nordic doctoral degree in music, and a tenured position in a highly ranked Latin American university. As can be gathered so far, when I speak of colonization and decolonization in regard to being socialized around Western world views and artifacts, I do not do it as an Indigenous, ethnic, or sexual minority, or dispossessed, disabled, or immigrant. I do not speak on behalf of silent voices whom I do not represent in terms of my material and symbolic experiences. I am aware of the perversity of appropriating thinking produced by silent voices in one's academic ivory tower, and the contradictory messages conveyed when one preaches decolonial ideas stolen from subaltern trenches.

Bolivian Aymara sociologist and katarista movement activist Rivera Cusicanqui (2010) complains of some (usually male) scholars born in Latin America who

Rosabal-Coto, Guillermo. 2019. The day after music education. Action, Criticism, and Theory for Music Education 18 (3): 1-24. https://doi.org/10.22176/act18.3.1 
undertake a prestigious career in cultural studies departments in North American universities and have adopted postcolonial studies in their curricula. They lead debates "with a culturalist and academicist landmark ... stripped of the sense of political urgency that characterized intellectual quests in intellectual colleagues in (the Subaltern Studies Group in) India (57). They have "created a jargon, conceptual apparatus and reference forms ... that have distanced academic reflection from commitment to and dialogue with insurgent social forces" (57-8). In this article, I try, as much as possible, not to disseminate ideas and work by those authors, and resort mostly to authors from the Global South. I also try not to emulate the appropriation criticized by Rivera Cusicanqui.

In the end, what entitles me to speak about colonial-based oppression and in whose name do I speak, and why? I speak from awareness of my own psychological colonization, undertaken jointly by social actors and myself, consciously or unconsciously, torn between survival and desire (see Fanon 1968, 1984). Who I have become as a Central American-born non-heterosexual male, classical musician, learner, teacher, and travelling researcher in the geographical North and South, has struggled with the world vision, self-image, and social practices that I acquired in my lifelong itinerary, through family rearing, religion, formal education, and professional exercise. I have been subtly or overtly coerced to look up to and become in the image of an ideal Euro-American, male, Christian, rational, called to follow the path of civilization to become a developed individual, and therefore a legitimate, valid citizen of a global community-an outcome that ought to be visible in my teaching and my research. This psychological colonization is unique to Latin American contexts, because it has historically been forged by physical and emotional torture (e.g., Spanish Inquisition) and physical and sexual abuse by Spanish conquerors, in the name of civilization and the Christian God.

I do not despise or reject the North and South that struggle and embrace each other within me. My unique border locus "is not mere awareness or antagonism, or resistance, but an active act to delink and look to other possible, co-existing worlds" (Rosabal-Coto 2016b; Anzaldúa 1987; Mignolo 2007). I have come to terms with both the privilege and discrimination that have forged me. In fact, as I have previously expounded (Rosabal-Coto 2006, 2016a), this very border location is the place where the question emerged that has triggered my research for years, a question to which musicians and music educators may easily relate: Why does 
music learning need to hurt your body, and why do you have to become someone you are not in order to gain social legitimacy?

After many years of research, I concluded that music socialization in post-independence Costa Rica has operated under the rationale to convert individuals into Euro-American, White artists or citizens. For education to succeed in this goal, it is necessary that the music learner is negated in their ways to be in and engage with music, and constructed by family, teachers, peers, and themselves as inferior subalterns. Their traits, memories, sensations, histories, and cognitive make-up are insufficient or in need of accommodation or modification in order to comply with the standards of an ideal individual. The appropriation and control of their bodies, emotions, and self-image, through authoritative notions and practices such as the term nivel (Sp. level, degree of), psychological violence (Rosabal-Coto 2013), and coercive practices like recruitment and admission, exams and juries, and massive instrumental instruction modeled after Venezuela's El Sistema (Rosabal-Coto 2016a), resembled how the Indigenous of what became Latin America were instilled with a self-concept of inferior subaltern though conversion to Catholicism and the encomienda-a "forced labor supply to the invaders, because the Amerindians had to be redeemed from the primitiveness and barbarism of their bodies" (Rosabal-Coto 2016b, 174). In such findings, I was able to see coloniality coordinating my upbringing and schooling. And by means of the coloniality that shapes notions and practices in (music) socialization, a line is drawn between the legitimate and the invalid-an action that Santos (2010) terms abyssal thinking (see Avis this issue; Walker this issue).

\section{(Dis)Closure: The day after music education}

Dear reader,

I address you as a music learner, colleague teacher/researcher, respectfully and with urgency. Even though I make strong arguments against colonization in this article, I do not intend to play the intellectual colonizer by imposing my world views and political ideas about decolonization on you. Santos (2014) contends that absent or silenced knowledges, world visions, and ways of being may not necessarily need to be located in the geographical South. Both you and I, whether in the geographical North or South, may be the subjects of absent, silenced knowledge in the name of civilization/development. 
I write to you because, as Rivera Cusicanqui (2004) warns, it would be hypocritical to try to decolonize ourselves alone. It would also be hypocritical to attempt to decolonize as long as we are not willing to question and give up power that sustains our privileges. Thus, in this call, I do not reflect on how music education as an abstract institution colonizes/decolonizes, but on how you and I-historical people-are able or willing to do so. And it is urgent to consider decolonization seriously because it might be almost too late, just like climate change, as an outcome of (colonial) extractivism in the name of civilization/progress/modernity and development, is perhaps too late to reverse (Lafontant Di Niscia, this issue).

Paraphrasing Patel (2016), perhaps, dysfunctionality is a useful term to illustrate how we (teachers, learners, parents, peers, researchers) are colonizers in music socialization, in our becoming the (Western-based) institution-understood as "coordinated and intersecting work processes and courses of action" (Holstein and Gubrium 2011, 351). Paraphrasing Silva (Fundación Rosa Luxemburgo n.d.), we colonize by naming, ordering, classifying, normalizing, homogenizing, planning, regulating, gathering/separating, including/excluding, punishing/rewarding, assessing, establishing hierarchies and truths, according to an already constructed position of individuals within a world system (capitalist order), where one is legitimate and another is not, just like that. The historically-constructed North is the reference for worthwhile, legitimate, natural, and desirable, and for us enunciating "certainties about what to do and what not to do, what is false and what is true, which voices to listen and which to ignore, which knowledges to cultivate and which to silence" (1).

We carry out all of the above-whether we are aware of it or not-in the name of capitalist/progressive, national/cultural, moral/ethical or aesthetic/scientific values, in the name of democracy, or just for the good of people, and by doing so we decide on the worth of what we and others look like, do, think, say, feel, learn, know, and express. Dysfunctionality does not come from generating damage or oppression per se. Neither does it come from being categorically racist, homophobic, or xenophobic, either. It comes from the act of damaging or oppressing in the name of elite/ethnoclass values, by physical, material or psychological violence upon others-legitimated through symbolic or material authority-in order to make those others feel and act as inferiors, so that they submit themselves to the elite world views and material organization that sustains a hegemonic world system, while they believe or are taught it is for their own good or betterment.

Rosabal-Coto, Guillermo. 2019. The day after music education. Action, Criticism, and Theory for Music Education 18 (3): 1-24. https://doi.org/10.22176/act18.3.1 
Decolonial thinking makes a difference conceptually, because it allows us to understand the historical and more recent structural origin of such dysfunctional dynamics, in deliberate material and symbolic processes of exploitation, beyond the hegemony of White, Western abstract narratives and categories that underpin curricula, pedagogy, policy, and research in a world order. It allows us to name specific, material acts of ethnoclasses and how the civilization/development values that sustain such acts continue to sustain what we say, do, teach, or research. It allows us to understand that music socialization has been constitutive of institutionalizing modern capitalism and neocolonialism. But if we stay in the thinking of only-“We're dysfunctional!"-, or become obsessed with creating more post-, anti-, trans-, or neo- concepts, and do not act in first person towards material change, we may end up perpetuating the world order that we are criticizing. Decolonial thinking is then useful because it envisions, proposes, and allows for material and structural, historical transformations of the modern/colonial, capitalist/patriarchal, Christian/Western-centric world system (Grosfoguel 2016).

At this point, I would like to pose the following questions for reflection, as a way to advance decolonial thinking in regard to the everyday life of music education professionals:

For those of us born, raised and educated in a capitalist order: Does the status and authority granted by the transcendent/heroic aura around conducting, composing, solo careers, teaching, and doing research cleanse or prevent us from the desire to accumulate, dispossess, and control-values that are foundational to this order? Does this make us socially qualified to set the example as social leaders and tell others the path suited to them? What would be left of us if stripped from the ableism narrative of the supernatural gift of music and the heroic role of musicians and teachers to touch lives and promote social change?

Bestowed with the above status and authority, we are taught to manipulate and intervene in other's lives and spaces through pedagogical and research methods. We have to guide others to adapt (or give up adapting) to an ideal model of individual, something that may be far from their being or wanting. We do that just like imperial countries and international financial and development agencies intervene in countries where they have economic interest. Are we aware of how many people we have dismissed, misrepresented, exploited, or failed under the criteria of not being good, able, scientific, or civilized enough, under premises of citizenship, 
long-standing pedagogies, national standards, competencies, and assessment practices?

The values of efficiency, productivity, excellence, and artistry call for us to exploit the time, physical and psychological energy, thoughts, effort, emotions of students, ensemble members, and research participants. We also make use of our own bodily resources and engage in a lifestyle that entails consumption of (expensive) quality musical instruments and sustain productive processes that entail labor exploitation and extractivism, and thus an ecocide lifestyle. Is living by these values sustainable? Do these values help people fulfill their fullest potential in harmony with our/their bodies, other humans, non-human beings, including nature? Are we aware of the toll, how we contribute to the crisis of civilization by damaging people and the environment, just for putting the goals of capitalism before our own physical and mental health and that of other living beings?

We can learn from the sumak kawsay (Lafontant Di Niscia, this issue) and suma qamaña world visions from Southern, Quechua-Ecuadoran and Aymara-Bolivian, respectively, good living and live well, as lived up to this day. By no means can these concepts be equaled to the Western (Greek) idea of good life associated with "contemplative life, development of intellect, body, arts, politics and possibility of having free time to do what the spirit demands" in the capitalist order (Medina 2006, 106). The above have become models of government organization in Ecuador and the plurinational state of Bolivia. But in this call, I suggest we reflect on their premise: to live well in interculturality and pluriversality, without asymmetries, in equilibrium with everything that surrounds us, including other nonhuman beings, and the natural environment, to guide inner decolonization, because we cannot live well if others live badly. I do not suggest the adoption of any Indigenous world view or activism as a theory to decolonize music education as a profession, as this may result in new fashions and trends to be dropped the next minute, as Bowman (2007) warned.

In his work Hacia el día después del desarrollo (Towards the day after development), Brazilian sociologist Silva (2011) contends, after Gudynas (2009), that it is necessary to imagine and create a day after progress/development. It would be unrealistic to expect to "begin" decolonization at the top of educational institutions, through policy or mandate to be observed or obeyed. It is very unlikely that decolonization happens because a respected activist delivers a skillful speech, or after we commit to making sense of decolonial theory through class readings and

Rosabal-Coto, Guillermo. 2019. The day after music education. Action, Criticism, and Theory for Music Education 18 (3): 1-24. https://doi.org/10.22176/act18.3.1 
discussions. Over the years, I have seen people who take my university courses and attend my international workshops unconsciously support the structures that we questioned in class just a minute ago. It is common, too, that decolonial thinkers are not considered reliable when they publicly display contradictions between what they preach and practice. So, there is more to decolonization than an epiphany or well-intended initiative, or even a metaphor.

Decolonization is not the fruit of awareness on one idea or concept only, and it certainly does not happen overnight. It can only begin in the flesh and experience of each human being, in everyday life choices, and is both an individual and collective process. We should be aware whether or not we are prepared to engage in it in our flesh, and to what degree(s) of responsibility and action we are willing to engage, as we listen to the interplay of desires, privileges, needs, convictions, vulnerabilities, insecurities, certainties, interests, and ideals, forged in our primary, secondary, and tertiary socialization. Despite shared upbringing, education, religion, professional goals, political convictions, and institutional affiliation, is it likely that every person understands coloniality in the particular experiences of their life, and express or commit to decolonization (or not) in divergent and unique ways. I think we should take full responsibility for our choices as colonized and colonizers and do so in collectivity.

Yours in good will, to live well,

Guillermo

\section{About the Author}

Guillermo Rosabal-Coto is a Professor of Music Education at Universidad de Costa Rica and Visiting Scholar at the Latin American Studies Program, University of Toronto, Canada. He founded and coordinates Observatorio del Musicar (Observatory of Musicking), an interdisciplinary teaching and research project based in his home university, that seeks to operationalize Christopher Small's concept of musicking in critical and decolonial pedagogies.

\section{Acknowledgements}

The author expresses his gratitude to Vincent Bates (former Editor of ACT), for the commission of this special issue, and to Deborah Bradley (current co-Editor), for her enormous help in reviewing, editing, and providing advice during the process, in the midst of very challenging personal circumstances. 
The author appreciates the commitment and patience of the authors at all times, as well as the time and input from Favio Shifres and Daniel H. Gonnet, and from reviewers in three languages.

The author acknowledges the outstanding job by the following article translators: Helena Perez Coelho (Brazil), Janette Kristine DeLong (Canada), and Juan Carlos Trejos and Katherine Arce Méndez (Costa Rica).

The author is grateful to Costa Rican cultural critic Jacobo Schifter, and Brazilian sociologist José de Souza Silva, for their help and crucial advice during this process.

Both this article and the special issue were completed through a research project as Visiting Scholar 2018-20 at the Latin American Studies Program, University of Toronto. The project received financial and administrative support through Facultad de Artes and Instituto de Investigación en Arte, Universidad de Costa Rica.

\section{References}

Anzaldúa, Gloria. 1987. Borderlands/La Frontera. San Francisco, California: Aunt Lute Books.

Ashcroft, Bill, Gareth Griffiths, and Helen Tiffin. 1998. Key concepts in postcolonial studies. New York: Routledge.

Bradley, Deborah. 2017. Interrogating the grammars of institutions and injustice. Action, Criticism, and Theory for Music Education 16 (3): 1-14.

Bowman, Wayne D. 2007. Who's asking? (Who's answering?) Theorizing social justice in music education. Action, Criticism, and Theory for Music Education 6 (4): 1-20. http://act.maydaygroup.org/articles/BowmanEditorial6_4.pdf

Bowman, Wayne D. 2006. Why narrative? Why now? Research Studies in Music Education 27 (1): 5-20.

Burcet, María I. 2017. Hacia una epistemología decolonial de la notación musical [Towards a decolonial epistemology of music notation]. Revista Internacional de Educación Musical 5: 129-38.

Carabetta, Silvia. 2017. Reflexiones para la construcción de una educación musical intercultural: Cuando lo pedagógico y lo epistemológico se desencuentran [Reflections towards the construction of an intercultural music education: 
When pedagogical and epistemological aspects become disengaged]. Revista Internacional de Educación Musical 5: 119-27.

Castro-Gómez, Santiago. 2008. (Post)coloniality for dummies: Latin American perspectives on modernity, coloniality, and the geopolitics of knowledge. In Coloniality at large. Latin America and the postcolonial debate, edited by Mabel Moraña, Enrique Dussel, and Carlos A. Jáuregui, 259-85. Durham and London, United Kingdom: Duke University Press.

Castro, Sebastián T. 2017. Una pedagogía bonsái al servicio de la colonialidad del ser y saber musical. Un estudio en perspectiva autoetnográfica [A bonsai pedagogy at the service of coloniality of being and coloniality of knowledge. A study in ethnographic perspective]. Revista Internacional de Educación Musical 5: 139-47.

Cox, Oliver C. 1959. The foundation of capitalism. London, UK: Peter Owen.

Fanon, Frantz. 1968. Black skin: White masks. London: Pluto Press.

Fanon, Frantz. 1984. The wretched of the Earth. London: Penguin Press.

Freeman, Derek. 2000. Sex and hoax in Samoa. Current Anthropology 41 (4): 609-22.

Fundación Rosa Luxemburgo. n.d. La colonialidad de la institucionalidad del orden capitalista [Coloniality of the institutionality of the capitalist order]. Entrevista a José de Souza Silva (JSS) por la Fundación Rosa Luxemburgo.

Gonnet, Daniel H. 2017. La construcción de conocimientos pluriversales en la escena del tango de principios de siglo XXI . La experiencia de la Escuela Orlando Goñi [The construction of pluriversal knowledge in the tango scene at the beginning of the 21st century. The case of Orlando Goñi School]. Revista Internacional de Educación Musical 5: 111-18.

Grosfoguel, Ramón. 2016. Caos sistémico, crisis civilizatoria y proyectos descoloniales: Pensar más allá del proceso civilizatorio de la modernidad/ colonialidad [Systemic chaos, civilizatory crisis, and decolonial projects: Thinking beyond the civilizatory process of modernity/ coloniality]. Tabula Rasa 25: 153-74.

Gudynas, Eduardo. 2009. El día después del desarrollo [The day after development]. América Latina en movimiento 445: 31-3. 
Hess, Juliet. 2017. Equity and music education: Euphemisms, terminal naivety, and Whiteness. Action, Criticism, and Theory for Music Education 16 (3): 1547. https://doi.org/10.22176/act16.3.15

Holguín, Pilar J. 2017. La música desde el Punto Cero. La colonialidad de la teoría y el análisis musical en la universidad [Music from Zero Point. Coloniality of music theory and musical analysis at the university level]. Revista Internacional de Educación Musical 5: 149-56.

Holguín, Pilar J. and Favio Shifres. 2015. Escuchar música al sur del Río Bravo: Desarrollo y formación del oído musical desde una perspectiva latinoamericana [Listening to music in the South of Río Bravo: Musical ear construction and formation from a Latin American perspective]. Calle 1410 (15): 40-53.

Holstein, James A. and Jaber F. Gubrium. 2011. The constructionist analytics of interpretive practice. In The SAGE handbook of qualitative research, edited by Norman K. Denzin and Yvonna S. Lincoln, 341-57). Thousand Oaks, California: SAGE.

Johnson, Daniel C. 2010. Where wild flowers grow: A Costa Rican adventure. The Orff Echo. (Summer): 19-23.

Lafontant Di Niscia, Attilio. 2017. Sobre el proceso de adquisición de instrumentos musicales de El Sistema. Hacia una epistemología ecológica en la educación musical [On the process of acquisition of musical instruments in El Sistema. Towards an ecological epistemology in music education]. Revista Internacional de Educación Musical 5: 157-64.

Medina, Javier. 2006. Suma qamaña. Por una convivialidad posindustrial [Suma qamaña. Towards a postindustrial conviviality]. La Paz, Bolivia: Garza Azul Editores.

Mignolo, Walter D. 2011. Modernity and decoloniality. In Oxford Bibliographies. Retrieved from http://www.oxfordbibliographies.com/view/document/obo9780199766581/obo-9780199766581-0017.xml

Mignolo, Walter D. 2007. La idea de América Latina. Herida colonial y la opción decolonial [The idea of Latin America. Colonial wound and the decolonial option]. Spain: Gedisa.

Niknafs, Nasim. 2018. Tehran's epistemic heterotopia resisting music education. Philosophy of Music Education Review 26 (2): 55-175. https://doi.org/ 10.2979/philmusieducrevi.26.2.04 
Patel, Leigh. 2016. Decolonizing educational research. From ownership to answerability. New York: Routledge.

Quijano Aníbal, and Immanuel Wallerstein. 1992. Americanity as a concept; or the Americas in the modern world system. International Social Science Journal 1 (134): 549-56.

Quijano, Aníbal. 2000. Coloniality of power, Eurocentrism and Latin America. Nepantla, Views from South 1 (3): 533-89.

Rivera Cusicanqui, Silvia. 2010. Ch’ixinakax utxiwa: Una reflexión sobre prácticas y discursos descolonizadores [Ch'ixinakax utxiwa: A reflection on decolonizing practices and discourses]. Buenos Aires, Argentina: Tinta Limón.

Rosabal-Coto, Guillermo. 2006. On (gay) self-awareness in a music education foundations course: A Latin American experience. Gender, Education, Music, and Society 4 (1).

Rosabal-Coto, Guillermo. 2013. "I did it my way!": A case study of resistance to coloniality in music learning and socialization, Action, Theory and Criticism for Music Education 13 (1): 154-87. http://act.maydaygroup.org/articles/Rosabal-Coto13_1.pdf

Rosabal-Coto, Guillermo. 2016a. Costa Rica's SINEM: A perspective from postcolonial institutional ethnography. Action, Theory and Criticism for Music Education (15) 1: 154-87. http://act.maydaygroup.org/articles/RosabalCoto15_1.pdf

Rosabal-Coto, Guillermo. 2016b. Music learning in Costa Rica: a postcolonial institutional ethnography. Studia Musica 68. The Sibelius Academy of the University of the Arts Helsinki. http://ethesis.siba.fi/files/rosabalcoto_ music_learning_in_costa_rica_pdf_studia_musica_68.pdf

Schifter, Jacobo. 1989. Homosexualidad y SIDA en Costa Rica. La formación de una contracultura [Homosexuality and AIDS in Costa Rica. The formation of a counterculture]. San José, Costa Rica: Editorial Guyacán.

Serrati, Pablo S. 2017. Cuestionar la colonialidad en la educación musical [Questioning coloniality in music education]. Revista Internacional de Educación Musical 5: 93-101.

Shifres, Favio, and Daniel H. Gonnet. 2015. Problematizando la herencia colonial en la educación musical [Problematizing the colonial legacy in music education]. Epistemus 3 (2): 51-67. 
Shifres, Favio, and Guillermo Rosabal-Coto. 2017. Hacia una educación musical decolonial en y desde Latinoamérica [Towards a decolonial music education in and from Latin America]. Revista Internacional de Educación Musical 5: 8591.

Smith, Dorothy E. 2005. Institutional ethnography. A sociology for people. Maryland: Altamira.

Santos, Boaventura de Sousa. 2010. Descolonizar el saber, reinventar el poder [To decolonize knowledge, to reinvent power]. Montevideo, Uruguay: Ediciones Trilce.

Santos, Boaventura de Sousa. 2014. Epistemologies of the South: Justice against epistemicide. London, UK: Taylor and Francis.

Silva, José de Souza. 2011. Hacia el día después del desarrollo [Towards the day after development]. Paraíba, Brazil: Asociación Latinoamericana de Educación Radiofónica.

Tuck, Eve, and K. Wayne Yang. 2012. Decolonization is not a metaphor. Decolonization: Indigeneity, Education \& Society 1 (1): 1-40.

Vázquez Córdoba, Héctor M. 2017. La educación musical como oportunidad para el aprendizaje de la cosmovisión de los pueblos indígenas en el sistema educativo mexicano: El caso de La Huasteca [Music education as an opportunity to learn indigenous people's worldviews in the Mexican educational system: The case of La Huasteca]. Revista Internacional de Educación Musical 5: 103-10.

Wynter, Sylvia. 2003. Unsettling the coloniality of being/power/truth/freedom: Towards the human, after man, its overrepresentation-an argument. The New Centennial Review 3 (3): 257-337. 